\title{
Selection against inbreds in early life-cycle phases in Pinus leucodermis Ant.
}

\author{
M. MORGANTE*, G. G. VENDRAMIN $\dagger, P$. ROSSI \& A. M. OLIVIERI \\ Dipartimento di Produzione Vegetale e Tecnologie Agrarie, Università di Udine, Via Fagagna 208, 1-33100 Udine and \\ $\dagger$ Istituto Miglioramento Genetico Piante Forestali, C.N.R., Via San Bonaventura 13, 1-50145 Udine, Italy
}

\begin{abstract}
Conifers are self-compatible hermaphroditic plants which usually show very low levels of selfing and severe inbreeding depression. Positive fixation indices are observed in the seed stage owing to partial selfing but not in the adult stage and selection against inbreds has been frequently invoked to explain this observation. To determine the stage of elimination of inbreds in Pinus leucodermis Ant., a narrow-ranged and relic species characterized by $18-28$ per cent selfing rates, fixation indices at isozyme gene loci were estimated in nursery grown individuals at three different juvenile life-cycle phases and in adult parent trees. Two populations with different levels of selfing were studied. In both populations a deficiency of heterozygotes as a result of selfing was observed in dormant and in germinated embryos, while an excess of heterozygotes comparable with that of the adult trees was found in 5-year-old plantlets. Young plantlets of the same two populations grown in the wild also had negative fixation indices confirming that selection takes place in the first years of growth.
\end{abstract}

Keywords: fixation indices, heterozygosity, inbreeding, Pinus leucodermis, seed germination, selection.

\section{Introduction}

Conifers are organisms that usually have very low levels of selfing (less than 10 per cent) and express severe inbreeding depression (Muona, 1989). Many studies have shown that positive fixation indices are observed in the seed stage, as a consequence of partial selfing, but not in the adult stage, where generally there is no evidence of inbreeding. Selection against inbred seedlings has frequently been invoked to explain this observation. Many of the selfed zygotes are expected to die before embryo maturation owing to homozygosity of embryonic lethal genes or to be eliminated as a result of the phenomenon of polyembryony (Sorensen, 1982). Despite this, even among the mature seeds some selfs are found. Demography of natural populations of conifers is such that only an extremely small portion of the mature embryos will survive to the adult stage, as a consequence of the heavy mortality that occurs during each of the life-cycle phases. Mortality is greater in early life-cycle phases but can be significant even later. Such mortality is partly random but it also has important genetic consequences, such as the elimination of inbred individuals.

*Correspondence.
The stage of elimination of inbreeds has not been clearly determined, even though it is of great concern, both from the ecological and economical point of view, especially in those species with higher self-fertility than usual, in which a relevant portion of inbreds survive to the mature seed stage.

It has been demonstrated in a previous study (Morgante et al., 1991) that Pinus leucodermis Ant., a conifer with a discontinuous and restricted distribution in southern Europe, is characterized by much higher levels of self-fertilization than those usually found in conifers and that the partial selfing results in positive fixation indices in the dormant embryo (zygote) stage, but not in the adult parental trees. The present study was therefore undertaken to determine the stage of elimination of inbreds in seedlings of this species. The approach chosen involves obtaining multiple census data within a single generation (Fig. 1) from two populations characterized by different levels of selfing. We will hence examine genetic changes, namely variation in the fixation indices, at isoenzyme marker loci during early life-cycle phases in nursery-grown individuals of Pinus leucodermis deriving from a single seed-cohort with a known level of inbreeding. Under these conditions selection can be assumed to be the only cause of genetic changes. The results will be compared with 
those obtained from the analysis of plantlets of the same two stands grown in natural conditions. Laboratory experiments, in fact, can support a theory but cannot assess its importance in natural populations, while comparative studies in the wild can demonstrate correlation but not causation (Endler, 1986).

\section{Materials and methods}

Cones were collected in 1985 in two Italian populations of Pinus leucodermis Ant., named La Spina $\left(40^{\circ} 07^{\prime} \mathrm{N}, 15^{\circ} 56^{\prime} \mathrm{E}\right.$, altitude $900 \mathrm{~m}$ a.s.l.) and Pollinello $\left(39^{\circ} 54^{\prime} \mathrm{N}, 16^{\circ} 11^{\prime} \mathrm{E}\right.$, altitude $1800 \mathrm{~m}$ a.s.1.), from 28 and 20 adult trees, respectively.

Seeds were extracted using standard techniques and parental identity was maintained. Dormant seed tissues, i.e. embryo and endosperm (megagametophyte), were simultaneously assayed at four unlinked polymorphic enzyme gene loci (Morgante et al., 1993), glutamate oxalate transaminase (GOT-A and GOT-C) (E.C. 2.6.1.1), phosphoglucomutase (PGM-A) (E.C. 2.7.5.1) and shikimate dehydrogenase (SKD-A) (E.C. 1.1.1.25). This allowed the identification of genotypes of adult parental trees (adult census), the estimation of multilocus population outcrossing rate $\left(t_{\mathrm{m}}\right)$ (Ritland \& El-Kassaby, 1985) according to the mixed-mating model and the identification of zygote genotype (zygote census, Fig. 1).

Running conditions and staining methods for the enzyme markers used in this study are reported by Morgante et al. (1991).

Equal numbers of seeds per mother tree were then pooled and combined into a single lot representing each of the two populations. After a 40-day cold-moist stratification period, they were germinated at $20^{\circ} \mathrm{C}$ constant temperature by applying a 12 -h light photoperiod (Borghetti et al., 1989). When the radicle had emerged more than $2 \mathrm{~mm}$, germinated embryos were electrophoretically assayed (seedling census, Fig. 1).

Cumulative percentage of germination (CPG) was calculated after 30 days of germination counts. A part of the seeds from the combined seed lots was sown into pots and grown in a greenhouse with no artificial rearing and no fertilization until the age of 5 years, when plantlets were genotyped by assaying dormant bud tissues (plantlet census, Fig. 1). Less than 10 per cent of the sown seeds survived to this stage. Competition among seedlings might be the major cause of death, as a single individual of the 10-15 originally sown in each pot usually survived to the census time.

To compare the genetic structure of the plantlets grown under experimental conditions with that of those grown in natural stands, we collected bud samples from adult trees and young plantlets (approximately 5 years old) in the same two natural populations.

Observed and expected heterozygosity $\left(H_{\mathrm{o}}\right.$ and $\left.H_{\mathrm{e}}\right)$ were computed, for each of the populations and each of the life-cycle stages, and the fixation index $\left(F=1-H_{\mathrm{o}} / H_{\mathrm{e}}\right)$ (Brown, 1970) was estimated. Variance of $F$ was obtained according to Rasmussen (1964). Minimum variance means of the fixation index were estimated by weighting individual values by the inverses of their variance. The expected fixation index at inbreeding equilibrium $\left(F_{\mathrm{e}}\right)$, i.e. when all Hardy-Weinberg assumptions, beside random mating, are met, was computed as $\left(1-t_{\mathrm{m}}\right) /\left(1+t_{\mathrm{m}}\right)$ (Allard et al., 1968), where $t_{\mathrm{m}}$ is the multilocus outcrossing rate. Minimum variance means of fixation indices $F$ 's were then compared with each other and with $F_{\mathrm{e}}$ by using the Student's $t$-test, according to Kesseli and Jain (1985).

\section{Results and discussion}

Selfing rates of 28 and 18 per cent $\left(s=1-t_{\mathrm{m}}\right)$ were estimated for the 1985 seed cohort in $\mathrm{La}$ Spina and Pollinello populations, respectively (Table 1) (Morgante et al., 1991) by assaying dormant seeds. Both estimates were significantly different from 0 . Although several studies in conifers have recorded a reduction in germination percentage in selfed seeds

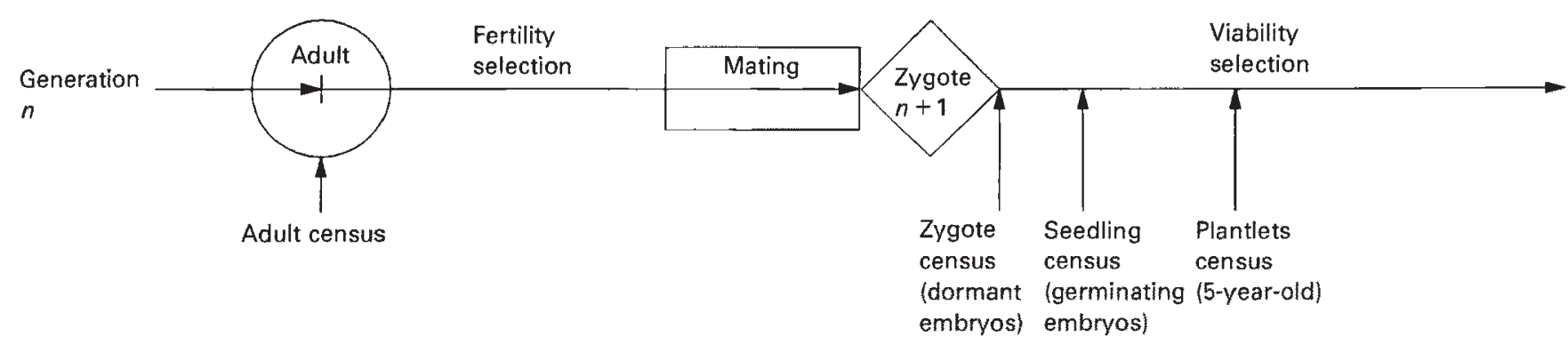

Fig. 1 A schematic diagram of the life cycle in Pinus leucodermis in which the points at which census data were obtained are indicated. (Modified from Clegg et al., 1978). 
Table 1 Multilocus outcrossing rates $\left(t_{\mathrm{m}}\right)$ and their standard errors and cumulative percentage of germination in the two populations studied

\begin{tabular}{lcc}
\hline & La Spina & Pollinello \\
\hline$t_{\mathrm{m}}$ & 0.723 & 0.824 \\
S.E. & 0.030 & 0.023 \\
CPG $(\%)$ & 81 & 40 \\
\hline
\end{tabular}

$\mathrm{CPG}=$ Cumulative percentage of germination, $t_{\mathrm{m}}=$ multilocus outcrossing rate.

(Franklin, 1970), this relation was not obvious in our samples under the adopted experimental conditions. Germination was in fact higher in the more selfed seed $\operatorname{lot}($ Table 1).
Observed and expected heterozygosity, fixation indices at single loci and their minimum variance means in adult trees, zygotes, seedlings and plantlets grown under nursery condtions from $\mathrm{La}$ Spina and Pollinello populations are reported in Table 2. GOT-A data are not reported for La Spina because the locus was monomorphic.

A constant trend in variation of the fixation index was observed in both populations at all loci and is clearly recognizable when mean values are considered. $F$ was negative, thus indicating the presence of an excess of heterozygotes, and significantly different from the expected fixation index at inbreeding equilibrium $\left(F_{\mathrm{e}}\right)$ in the adult trees which produced the analysed seeds in both populations. Adult $F$ was, furthermore, significantly different from 0 in the Pollinello population only. $F$ values were significantly positive

Table 2 Observed and expected heterozygosities, fixation indices and their standard errors in adult trees, zygotes, seedlings and plantlets from La Spina and Pollinello populations grown under nursery conditions

\begin{tabular}{|c|c|c|c|c|c|c|c|c|c|}
\hline \multirow[b]{2}{*}{ Locus } & & \multicolumn{4}{|l|}{ La Spina } & \multicolumn{4}{|l|}{ Pollinello } \\
\hline & & $\begin{array}{l}\text { Adult } \\
\text { trees }\end{array}$ & $\begin{array}{l}\text { Dormant } \\
\text { embryos } \\
\text { (zygotes) }\end{array}$ & $\begin{array}{l}\text { Germinating } \\
\text { embryos } \\
\text { (seedlings) }\end{array}$ & Plantlets & $\begin{array}{l}\text { Adult } \\
\text { trees }\end{array}$ & $\begin{array}{l}\text { Dormant } \\
\text { embryos } \\
\text { (zygotes) }\end{array}$ & $\begin{array}{l}\text { Germinating } \\
\text { embryos } \\
\text { (seedlings) }\end{array}$ & Plantlets \\
\hline \multirow[t]{5}{*}{ GOT-A } & $H_{0}$ & - & - & - & - & 0.350 & 0.176 & 0.210 & 0.393 \\
\hline & $H_{\mathrm{e}}$ & - & - & - & - & 0.289 & 0.205 & 0.254 & 0.315 \\
\hline & $F$ & - & - & - & - & -0.212 & 0.141 & 0.175 & -0.244 \\
\hline & $S . E_{._{F}}$ & - & - & - & - & 0.079 & 0.039 & 0.040 & 0.050 \\
\hline & $N$ & - & - & - & - & 20 & 1072 & 944 & 56 \\
\hline \multirow[t]{5}{*}{ GOT-C } & $H_{\mathrm{o}}$ & 0.214 & 0.160 & 0.158 & 0.273 & 0.100 & 0.046 & 0.048 & 0.125 \\
\hline & $H_{\mathrm{e}}$ & 0.196 & 0.160 & 0.166 & 0.244 & 0.095 & 0.064 & 0.066 & 0.116 \\
\hline & $F$ & -0.091 & 0.001 & 0.045 & -0.118 & -0.053 & 0.288 & 0.277 & -0.067 \\
\hline & $S . E_{\cdot_{F}}$ & 0.107 & 0.033 & 0.044 & 0.107 & 0.032 & 0.073 & 0.075 & 0.019 \\
\hline & $N$ & 28 & 951 & 696 & 33 & 20 & 1074 & 958 & 56 \\
\hline \multirow[t]{5}{*}{$P G M-A$} & $H_{\mathrm{o}}$ & 0.286 & 0.260 & 0.257 & 0.235 & 0.400 & 0.243 & 0.277 & 0.418 \\
\hline & $H_{\mathrm{c}}$ & 0.294 & 0.326 & 0.306 & 0.208 & 0.320 & 0.267 & 0.317 & 0.420 \\
\hline & $F$ & 0.026 & 0.201 & 0.161 & -0.133 & -0.250 & 0.092 & 0.127 & 0.004 \\
\hline & $S . E_{\cdot F}$ & 0.195 & 0.034 & 0.042 & 0.049 & 0.086 & 0.035 & 0.036 & 0.135 \\
\hline & $N$ & 28 & 1072 & 733 & 34 & 20 & 1063 & 965 & 55 \\
\hline \multirow[t]{5}{*}{$S K D-A$} & $H_{\mathrm{o}}$ & 0.423 & 0.242 & 0.262 & 0.242 & 0.450 & 0.283 & 0.311 & 0.321 \\
\hline & $H_{\mathrm{e}}$ & 0.375 & 0.323 & 0.323 & 0.258 & 0.399 & 0.319 & 0.332 & 0.270 \\
\hline & $F$ & -0.128 & 0.250 & 0.192 & 0.057 & -0.129 & 0.111 & 0.063 & -0.191 \\
\hline & S. $E_{F_{F}}$ & 0.173 & 0.037 & 0.043 & 0.190 & 0.203 & 0.034 & 0.034 & 0.045 \\
\hline & $N$ & 26 & 970 & 693 & 33 & 20 & 1066 & 952 & 56 \\
\hline \multirow[t]{3}{*}{ Mean } & $F$ & -0.079 & $0.142^{*}$ & $0.134^{*}$ & -0.121 & -0.095 & $0.126^{*}$ & $0.128^{*}$ & -0.101 \\
\hline & $S . E_{._{F}}$ & 0.083 & 0.020 & 0.025 & 0.043 & 0.028 & 0.020 & 0.020 & 0.016 \\
\hline & $F_{\mathrm{e}}$ & 0.159 & 0.159 & 0.159 & 0.159 & 0.096 & 0.096 & 0.096 & 0.096 \\
\hline$t$-test & $F=F_{\mathrm{e}}$ & $P<0.05$ & n.s. & n.s. & $P<0.01$ & $P<0.01$ & n.s. & n.s. & $P<0.01$ \\
\hline
\end{tabular}

$N=$ number of individuals sampled.

* Significantly different from adult and plantlet $F$.

For abbreviations see Materials and methods. 

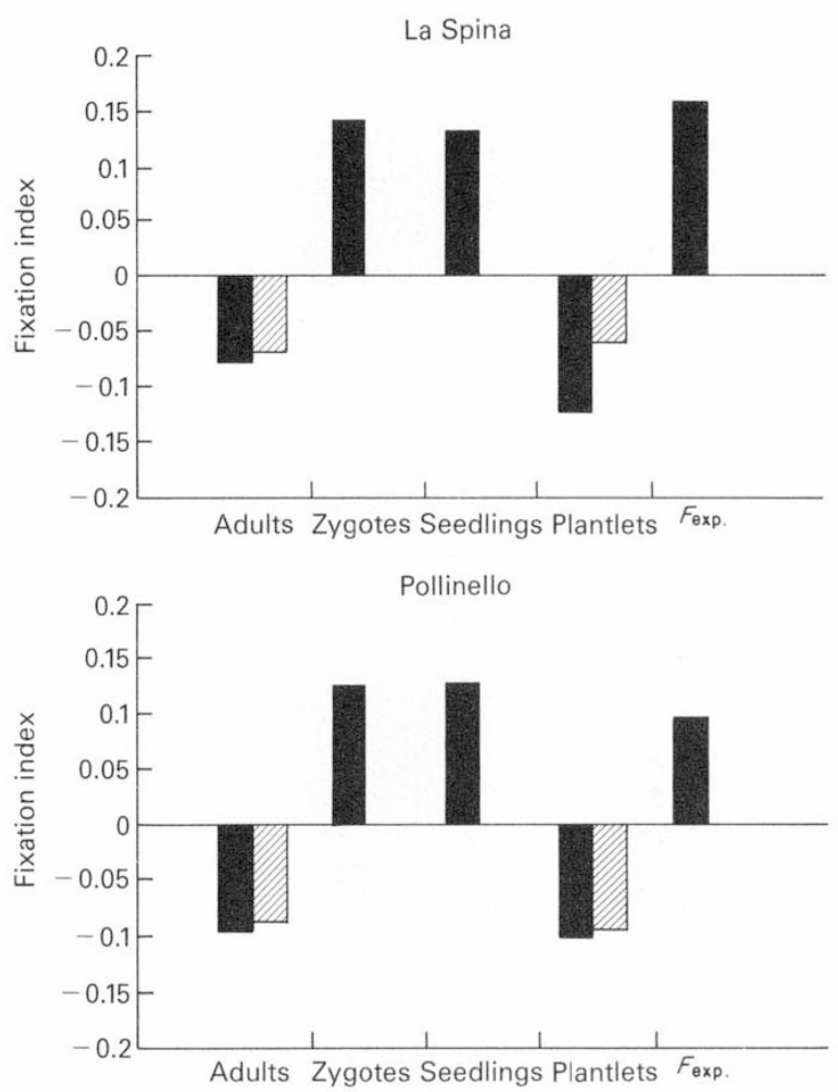

Fig. 2 Variations in fixation indices observed in the $(\mathbf{\square})$ nursery experiment and $(\mathbb{z})$ natural population.

and statistically not different from $F_{\mathrm{e}}$, thus reflecting the levels of inbreeding expected from the estimated amount of selfing, in the dormant embryo (zygote) stage and also in the germinated embryo (seedling) stage. $F$ values in these two stages were significantly different, as indicated by $t$-test, from the $F$ of both adults and plantlets. Fixation index in the plantlet stage was again negative, showing an excess of heterozygotes similar to that of adult parental trees, and significantly different from 0 and $F_{\mathrm{e}}$.

Analysis of inbreeding coefficients hence revealed that under the experimental conditions we adopted, which may be different from those experienced in natural populations, selection against inbred progenies did not act during seed germination, although mortality in this phase was considerable, especially in the Pollinello seed lot ( 60 per cent), and the long germination times typical of this species (Borghetti et al., 1989), whose seeds are characterized by a pronounced dormancy. Perry and Knowles (1991) found no statistically significant differences in outcrossing rates during germination in Thuya occidentalis L., a species characterized by a high level of inbreeding (Perry and Knowles; 1990).
Inbreeding depression acted, on the contrary, after germination so that in the 5-year-old plantlets, which had experienced an overall mortality rate of more than 90 per cent, the levels of inbreeding typical of adult trees had been re-established. No effect of the different levels of selfing of the two populations on the selective patterns was observed.

Plantlets of the same two populations grown in natural conditions were analysed, together with the adult trees surrounding them, to verify whether the variations in fixation indices observed in the nursery experiment portrayed the genetic changes occurring in natural populations or had been heavily influenced by the experimental conditions (Fig. 2). The analysis of the variation of the $F$ values between different lifecycles stages in natural conditions is a much more realistic approach but, on the other hand, it has some limits: levels of inbreeding in the seed cohort plantlets derived from them is not known (temporal variation in the outcrossing rates has been described in forest tree populations (Brown et al., 1985)) and plantlets probably derive from different seed cohorts, because they are not even-aged.

Fixation indices of approximately 5-year-old plantlets grown in the wild were not significantly different from those of adult trees (Table 3) and no statistically significant difference has been found between the $F$ values scored in artificial and natural conditions.

Our results therefore indicate that inbreds are not efficiently eliminated during seed maturation and germination. However, inbreds had been eliminated before the plantlets were 5 years old and heterozygotes were favoured both in the nursery and in natural conditions, in which different selective pressures probably occurred.

Interestingly enough similar observations have been reported for Serbian spruce (Picea omorika), another endemic and extremely narrow-ranged species, in which the onset of inbreeding depression is weak in the early development of the zygote, but strong in later growth (Kuittinen et al., 1991).

The stage of elimination of inbreds has been studied in only a few forest species. In Pinus sylvestris, Tigerstedt et al. (1982) found evidence of inbreeding even in 100-year-old trees while, on the contrary, homozygote excess has been shown to be eliminated in a different natural stand by the age of 10 years (Yazdani et al., 1985). Moreover, Muona et al. (1987) found in the same species evidence of elimination of inbred seedlings, examining the genetic changes after the seed stage in nursery-grown seedlings, after 2 years of growth in the field. Farris and Mitton (1984) observed differences between $F$ values of germinated seeds and 5-month-old seedlings in Pinus ponderosa 
Table 3 Observed and expected heterozygosities, fixation indices and their standard errors in adult trees and plantlets from La Spina and Polinello populations grown in natural conditions

\begin{tabular}{|c|c|c|c|c|c|}
\hline \multirow[b]{2}{*}{ Locus } & & \multicolumn{2}{|l|}{ La Spina } & \multicolumn{2}{|l|}{ Pollinello } \\
\hline & & Adult trees & Plantlets & Adult trees & Plantlets \\
\hline \multirow[t]{5}{*}{$G O T-A$} & $H_{0}$ & - & - & 0.333 & 0.300 \\
\hline & $H_{\mathrm{e}}$ & - & - & 0.278 & 0.255 \\
\hline & $F$ & - & - & -0.200 & -0.176 \\
\hline & $S . E_{._{F}}$ & - & - & 0.063 & 0.042 \\
\hline & $N$ & - & - & 30 & 60 \\
\hline \multirow[t]{5}{*}{ GOT-C } & $H_{0}$ & 0.200 & 0.246 & 0.100 & 0.115 \\
\hline & $H_{\mathrm{c}}$ & 0.184 & 0.223 & 0.095 & 0.108 \\
\hline & $F$ & -0.084 & -0.103 & -0.003 & -0.061 \\
\hline & $S . E_{F_{F}}$ & 0.103 & 0.035 & 0.026 & 0.019 \\
\hline & $N$ & 30 & 301 & 30 & 61 \\
\hline \multirow[t]{5}{*}{$P G M-A$} & $H_{\mathrm{o}}$ & 0.310 & 0.372 & 0.357 & 0.311 \\
\hline & $H_{\mathrm{c}}$ & 0.307 & 0.369 & 0.293 & 0.263 \\
\hline & $F$ & -0.010 & -0.008 & -0.217 & -0.184 \\
\hline & S.E.F. & 0.183 & 0.062 & 0.069 & 0.043 \\
\hline & $N$ & 29 & 258 & 28 & 61 \\
\hline \multirow[t]{5}{*}{$S K D-A$} & $H_{0}$ & 0.367 & 0.257 & 0.333 & 0.310 \\
\hline & $H_{\mathrm{e}}$ & 0.339 & 0.264 & 0.320 & 0.285 \\
\hline & $F$ & -0.080 & -0.027 & -0.042 & -0.088 \\
\hline & S.E.E. & 0.166 & 0.062 & 0.173 & 0.109 \\
\hline & $N$ & 30 & 284 & 30 & 58 \\
\hline \multirow[t]{2}{*}{ Mean } & $F$ & -0.069 & -0.060 & -0.089 & -0.096 \\
\hline & S.E.F & 0.079 & 0.027 & 0.022 & 0.016 \\
\hline
\end{tabular}

$N=$ number of individuals sampled.

For abbreviations see Materials and methods.

Laws., showing increased survival of more hetero.zygous individuals.

The timing of inbreeding depression effects may have important implications in designing ex situ conservation programmes, i.e. in establishing seed orchards or artificial populations for dynamic gene conservation. If nursery-grown seedlings have to be outplanted in order to create artificial populations, it is necessary to be sure that selection has already eliminated inbreds so as to avoid significant losses of individuals or pronounced inbreeding depression. This problem could be particularly serious for Pinus leucodermis, a species with high self-fertility. Effects of variations in different ecological factors (e.g. temperature, photoperiod, water and nutrient availability) and of different degrees of intraspecific competition on selective patterns in early life-cycle phases need to be evaluated.

\section{Acknowledgements}

M.M. was supported by a V. V. Landi Foundation Fellowship of the Accademia Nazionale dei Lincei.

\section{References}

ALLARD, R. W., JAIN, S. K. AND WORKMAN, P. L. 1968. The genetics of inbreeding populations. Adv. Genet., 14, 55-131.

BORGHETTI, M., VENDRAMIN, G. G., GIANNINI, R. AND SCHETTINO, A. 1989. Effects of stratification, temperature and light on germination of Pinus leucodermis. Acta Oecologica Oecologia Plantarum, 10, 45-56.

BROWN, A. D. H. 1970. The estimation of Wright's fixation index from genotypic frequencies. Genetica, 41, 399-406. BROWN, A. H. D., BARRETT, S. C. H. AND MORAN, G. F. 1985. Mating system estimation in forest trees: models, methods and meanings. In: Gregorius, H. R. (ed) Population Genetics in Forestry. Springer Verlag, Berlin, pp. 32-49. 
CLEGG, M. T., KAHLER, A. L. AND ALLARD, R. w. 1978. Estimation of Life cycle components of selection in an experimental plant population, Genetics, 89, 765-792.

ENDLER, J. A. 1986. Natural Selection in the Wild. Princeton University Press, Princeton, NY.

FARRIS, M. A. AND MITTON, J. B. 1984. Population density, outcrossing rate, and heterozygote superiority in ponderosa pine. Evolution, 38, 1151-1154.

FRANKLIN, E. C. 1970. A survey of mutant forms and inbreeding depression in species of family Pinaceae. USDA For. Serv. Res. Pap., SE-61.

KESSELI, R. V. AND JAIN, S. K. 1985. Breeding systems and population structure in Limnanthes. Theor. Appl. Genet., 71, 292-299.

KUITTINEN, H., MUONA, O., KÄRKKÄINEN, K. AND BORZAN, Z. 1991. Serbian spruce, a narrow endemic, contains much genetic variation. Can. J. For. Res., 21, 363-367.

MORGANTE, M., VENDRAMIN, G. G. AND OLIVIERI, A. M. 1991. Mating system analysis in Pinus leucodermis Ant.: detection of self-fertilization in natural populations. Heredity, 67, 197-203.

MORGANTE, M., VENDRAMIN, G. G. AND GIANNINI, R. 1993. Inheritance and linkage relationships of isozyme variants in Pinus leucodermis Ant. Silvae Gen., in press.

MUONA, o. 1989. Population genetics in forest tree improvement. In: Brown, A. H. D., Clegg, M. T., Kahler, A. L. and Weir, B. S. (eds) Plant Population Genetics, Breeding, and Genetic Resources. Sinauer Associates Inc., Sunderland, MA, pp. 282-298.
MUONA, O., YAZDANI, R. AND RUDIN, D. 1987. Genetic change between life stages in Pinus sylvestris: allozyme variation in seeds and planted seedlings. Silvae Gen., 36, 39-42.

PERRY, D. J. AND KNOWLES, P. 1990. Evidence of high self-fertilization in natural populations of eastern white cedar (Thuja occidentalis). Can. J. Bot., 68, 663-668.

PERRY, D. J. AND KNOWLES, P. 1991. Are inferred outcrossing rates affected by germination promptness? Silvae Gen., 40, 35-36.

RASMUSSEN, D. I. 1964. Blood group polymorphism and inbreeding in natural populations of deer mouse, Peromyscus maniculatus. Evolution, 18, 219-229.

RITLAND, K. AND EL-KASSABY, Y. A. 1985. The nature of inbreeding in a seed orchard of Douglas fir as shown by an efficient multilocus model. Theor. Appl. Genet., 71, 375-384. SORENSEN, F. C. 1982 . The roles of polyembryony and embryo viability in the genetic system of conifers. Evolution, 36, 725-733.

TIGERSTEDT, P. M. A., RUDIN, D., NIEMELA, T. AND TAMMISOLA, J. 1982. Composition and neighbouring effect in a naturally regenerating population of Scots pine. Silva Fennica, 16, 122-129.

YAZDANI, R., MUONA, O., RUDIN, D. AND SZMIDT, A. E. 1985. Genetic structure of a Pinus sylvestris L. seed-tree stand and naturally regenerated understory. Forest Sci., 31, $430-436$. 